\title{
Keskustelukumppanina Sharan B. Merriam
}

University of Georgia Athensin kaupungissa 80 mailia Atlantasta itään. Professori Sharan B. Merriamilla on juuri päättynyt kevään ensimmäinen aikuiskasvatuksen tutkielmaseminaari. Sen jälkeen tapaamme kampusalueella, Center for Continuing Education rakennuksessa, jonka tunnuksena komeilee universaalista aikuiskasvatusideologiasta tuttu lause "an equal opportunity institution".

Sharan B Merriam

Sharan B. Merriam on väitellyt kasvatustieteen tohtoriksi aikuiskasvatuksesta Rutgers Universityssä vuonna 1978. Ennen tuloaan University of Georgiaan hän on työskennellyt Northern Illinois Universityssä ja Virginia Polytechnic Institutessa sekä Virginia State Universityssä.

Keskustelumme aluksi viittaan erääseen Merriamin 1970-luvun loppupuolella kirjoittamaan artikkeliin, jossa hän käsittelee naisprofessorina olemista aikuiskasvatuksessa. Kysyn miten asiat ovat tällä hetkellä Amerikassa. Merriamin mukaan naisprofessoreiden määrä Yhdysvalloissa on koko ajan kasvamassa. Artikkelin kirjoittamisen ajoista, siis parissakymmenessä vuodessa, naisprofessorien määrä on suunnilleen kaksinkertaistunut. Heillä on tätä nykyä myös kiinteä naistutkijoiden verkosto, joka pitää yllä tiiviitä suhteita aikuiskasvatuksen kysymyksissä.

Merriam jakaa aikuiskasvatuksen Yhdysvalloissa tyypillisesti kahteen osaan, akateemiseen tutkimukseen ja käytännön aikuiskasvatukseen. Akateemisena oppiaineena aikuiskasvatustutkimus on kasvatustieteellisen tutkimuksen pienemmästä päästä. Aikuiskasvatukseen laskettavaa tutkimusta tehdään toki muissakin kuin varta vasten nimetyissä tiedekunnissa.

Käytännön toimintana aikuiskasvatus on laajin kasvatuksen alue, yhä laajenemassa, jos mukaan lasketaan yritysten henkilöstökoulutus ja henkilöstövoimavarojen kehittäminen (human resource development), korkeakoulutus, yhteisökasvatus, vankilakasvatus, sotilaskoulutus ja ammatillinen jatko- ja täydennyskoulutus. Näihin kaikkiaan aikuiskasvatuksen koulutusohjelmat valmistavat asiantuntijoita.

Kysymys siitä, mitkä asiat ovat tätä nykyään esillä Yhdysvalloissa käytävässä julkisessa aikuiskasvatuskeskustelussa, on Merriam mukaan aina, ei pelkästään nyt, sidoksissa keskusteluun julkisesta rahoituksesta. Kuumia aiheita ovat työvoiman pätevyys (workplace literacy) ja korkean ammattitaidon omaavien jatkokoulutus. Ensikädessä kyse on siitä, että aikuiskasvatusta rahoitetaan Amerikassa ainoastaan siinä määrin, kun se kykenee perustelemaan kulloisenkin toiminnan sen tuloksellisuuden ja tehokkuuden kannalta. Rahoituksen taustalla ovat demokratian ja yhteiskunnallisen status quon ideologiat. julkinen retoriikka perustuu ajatukseen, jossa jokaisen oletetaan olevan tuottelias ja aikaansaava. Kongressissa hermostutaan, jos yhteiskunnassa kyseenalaistetaan näitä perusarvoja. Kuulostanee osin tutulta suomalaisenkin korviin, mutta Merriamin mukaan kysymys on lopulta taloudellisen kilpailukyvyn säilyttämisestä suhteessa Euroopan Unioniin ja Kauko-idän markkinoihin.

Merriam sanoo Amerikassa kuitenkin olevan suhteellisen vahva ja elävä yhteisöaktivistinen aikuiskasvatusliike, jolle ei meikäläisittäin löydy tarkkaa vastinetta, mutta joka suurin piirtein vastaa vapaata sivistystyötä tai liberaalia aikuiskasvatusta. Tähän liikkeeseen kuuluu mm. rodullisia ja kulttuurisia 
vähemmistöjä sekä yliteisökasvattajia. jos heille hakee yhteistä nimittäjää, voidaan se löytää kriittisen aikuiskasvatuksen perinteestä. Täten he eivät myöskään nauti julkisesta rahoituksesta, koskapa kyseenalaistavat ja riitauttavat valtaeliitin näkemyksiä. Poikkeuksen muodostavat joidenkin yliopistojen naistutkimuksen ja feministisen pedagogiikan ryhmittymät, joiden kautta radikaaliksi laskettuja ajatuksia käsitellään myös ikään kuin järjestelmän sisällä.

\section{Aikuisen kehitys ja muutos}

Tutkijana professori Merriamia kiinnostaa nykyään se, kuinka aikuiset kasvavat, kehittyvät ja muuttuvat. Kysymys on aikuisuuden kehitystehtävien ja oppimisen vuorovaikutuksesta: kuinka oppiminen motivoi eriaikaista kehitystä aikuisuudessa ja vastaavasti kehitys oppimista. Parhaillaan Merriamilla on myös tekeillä uusi aikuiskasvatuksen yleisesitys vanhan Gary Darkenwaldin kanssa tehdyn tilalle, koska edellinen on Merriamin mukaan jo vanhentunut ja kaiken lisäksi sen painos on myyty loppuun. Vaikka yleisesitystä ehdottomasti tarvitaan, on sen laatiminen nykyään aikuiskasvatuksen hillittömän paisumisen ja hajanaisuuden vuoksi huomattavasti vaikeampi tehtävä kuin 1980-luvun alussa.

Laadullisen tutkimuksen puolella Merriain on ansioitunut myös ja kirjoittanut laadullisista tutkimusmenetelmistä kirjan. Merriain kertoo haluavansa korostaa ongelmalähtöistä lähestymistapaa. Samalla kun hän painottaa tutkimusmenetelmän valinnan seuraavan tutkimusongelman tematisoinnista, tuo hän esiin metodologisen liberalisminsa korostamalla kaikenlaisen ja monenmoisilla menetelmillä tehdyn aikuiskasvatustutkimuksen tärkeyttä. Sosiaalinen maailma ei moninaisuudessaan pakotu yhteen menetelmään, eikä avaudu yhden teoreettisen linssin läpi.

Keskustelumme valuu lopulta aikuiskasvatuksen ja postmodernin kysymyksiin ja juuttuu meneillään olevaan tietotekniseen vallankumoukseen, tiedon super highwayhin, ja sen merkitykseen aikuiskasvatuksen kannalta. Tietokoneiden ja tietoverkkojen sovelluksilla on tietenkin huimat mahdollisuudet aikuiskasvatuksessa, mutta kysymyksen kääntöpuoli on tietotekniikan mahdollisuuksien tasavertaisessa hyödyntämisessä. Niin hyvää kuin tietotekniikan kehitys voi monessa tapauksessa luvatakin, on sillä myös olemassa selviä ihmisten mahdolliseen vieraantumiseen johtavia sudenkuoppia. Haastateltava toteaa lopuksi aikuiskasvatuksella olevan edessään suuria tehtäviä jatkuvan muutoksen yhteiskunnissa. Oli kysymys aikuiskasvatustieteestä tai -käytännöstä, työt eivät tekevältä lopu.

Ahkerana ja tuotteliaana kirjoittajana tunnettu professori Merriain on tuottanut lukuisia tieteellisiä artikkeleita. Hän on ollut toimittamassa mm. aikuiskasvatuksen käsikirjaa yhdessä P Cunninghamin kanssa (Handbook of adult and continuing education, 1989). Merriam on kirjoittanut seuraavat teokset:

Philosophical foundations of adult education (\& J. Elias), 1980.

Coping with male mid-life, 1980.

Adult education: foundations of practice (\& G. Darkenwald), 1982.

Themes of adulthood through literature, 1983. A guide to research for educators and trainers of adults $(\&$ E. L. Simpson), 1983.

Adult development: implications for adult education, 1985.

Case study research in education, 1988.

Learning in adulthood (\& R. Caffarella), 1991. 